\title{
PERILAKU MEMILIH MASYARAKAT MANDAILING NATAL PADA PEMILIHAN KEPALA DESA
}

\author{
Rachmi Fatimah Nasution \\ Universitas Negeri Padang \\ rachmifatimahnasution93@gmail.com
}

\begin{abstract}
Abstrak
Penelitian ini bertujuan untuk mendeskripsikan perilaku memilih masyarakat Mandailing di Desa Iparbondar dalam pemilihan kepala desa tahun 2016, dan juga menganalisis rasionalitas memilih masyarakat Desa Iparbondar dalam Pilkades tahun 2016. Seringnya Marga mayoritas yang menjabat sebagai kepala desa memunculkan pertanyaan tentang apakah faktor etnis dan budaya yang mendominasi masyarakat dalam memilih calon tersebut, atau ada faktor lain yang menjadi pertimbangan masyarakat. Metode penelitian yang digunakan yaitu penelitian kualitatif deskriptif. Hasil penelitian menunjukkan bahwa masyarakat Desa Iparbondar cenderung menentukan pilihan berdasarkan pendekatan sosiologis yaitu kekerabatan, dan pemilih dari masyarakat Mandailing di Desa Iparbondar sebagian besar masih kurang rasional
\end{abstract}

Kata kunci: Demokrasi; Perilaku Pemilih; Pemilihan Kepala Desa. 


\title{
MANDAILING NATAL COMMUNITY VOTING BEHAVIOR IN VILLAGE HEAD ELECTION
}

\begin{abstract}
This study aims to describe the behavior of the Mandailing community in Iparbondar village in the 2016 village head election, and also analyze the rationality of choosing the village people in the village election in 2016. The village head is from majority of clans it appear some questions abaut what is the most dominating of society in choosing the candidate wether ethnic or culture factors or it is according to the opinion of societies. The reaserch were collected some data through documentation studies, observations and interviews. The result of the study showed that the people of Iparbodar village tended to make choices based on a sociological approach, namely kinship, and voters from Mandailing community in Iparbondar village were mostly still irrational.
\end{abstract}

Keyword: Democracy; Voting Behavior; Village Head Election. 


\section{A. PENDAHULUAN}

Dalam suatu Pemilihan Umum (Pemilu), Hal yang cukup menarik diperhatikan dalam partisipasi politik masyarakat adalah dinamika yang terjadi pada perilaku memilih. Setiap masyarakat memiliki preferensi dan kepentingan masing-masing untuk menentukan pilihan mereka dalam pemilu, mengapa pemilih memilih kontestan tertentu bukan kontestan lain. Bisa dikatakan bahwa masa depan pejabat publik yang terpilih dalam suatu Pemilu tergantung pada preferensi masyarakat sebagai pemilih.

Perilaku memilih tidaklah merupakan sesuatu yang berdiri sendiri tetapi perilaku pemilih tersebut dipengaruhi oleh faktor internal dan faktor eksternal. Dilihat dari pedekatan mengapa pemilih memilih kontestan tertentu bukan kontestan lain, dibedakan menjadi lima sesuai dengan pendekatan yang digunakan, yakni struktural, sosiologis, ekologis, psikologi sosial, dan pilihan rasional. Ajzen mengatakan bahwa sikap juga mempengaruhi perilaku lewat suatu proes pengambilan keputusan yang teliti dan beralasan, dan teori perilaku beralasan dinamai teori perilaku terencana yang mencakup 3 hal yaitu : 1). kayakinan tentang kemungkinan hasil dan evaluasi dari perilaku tersebut (behavior beliefs). 2). Persepsi individu terhadap harapan-harapan dari orang-orang yang berpengaruh dalam kehidupannya mengenai dilakukan atau tidak dilakukannya perilaku tertentu, persepsi ini sifatnya subjektif sehingga dimensi ini disebut norma subjektif (subjektive norm), 3). Serta keyakinan tentang adanya faktor yang dapat mendukung atau menghalangi perilaku dan kesadaran akan kekuatan faktor tersebut (control beliefs), ini berhubungan dengan kesempatan dan kemudahan yang ada ketika melakukan sesuatu. ${ }^{1}$

Penelitian yang dilakukan oleh Sebayang, menemukan bahwa perilaku pemilih etnis karo dalam pemilihan bupati di Kabupaten Karo periode 2010-2015 masih dipengaruhi oleh etnis, yaitu pemilih memilih calon karena sesuku. ${ }^{2}$ Figur dari calon juga dapat mempengaruhi masyarakat dalam memilih calon. Sedangkan Alamsyah dalam penelitiannya menjelaskan keputusan pemilih untuk memilih calon kepala desa

${ }^{1}$ Icek Ajzen, 1991, “Theory of Planned Behavior”, Organizational Behavior and Human Decision, Processes, 50 hal 179-211.

${ }^{2}$ Sebayang, Irma S, "Perilaku Pemilih Etnis Karo dalam Pemilihan Bupati Kabupaten Karo Periode 2010 2015”. Medan : Fisipol USU, 2012 
e-ISSN : 2621-4105

dipengaruhi oleh kelas sosial, kapasitas mengolah informasi, motivasi, media komunikasi dan isu-isu politik. ${ }^{3}$

Desa Iparbondar yang berada di Kabupaten Mandailing Natal dikenal masih sangat homogen yang mana hanya terdapat Etnis Batak Mandailing dan masyarakatnya beragama Islam. Masyarakatnya terdiri dari dua marga besar yaitu Lubis dan Nasution . Pada Silsilah Marga Batak Mandailing marga diatas adalah satu, yang artinya memiliki ikatan kekerabatan yang cukup kuat dan dekat. ikatan kekerabatan berdasarkan marga di daerah Mandailing disebut Dalihan na tolu yaitu, tiga kelompok yang berlainan marga rangkul-merangkul atau harus bersatu padu seia sekata menjadi satu. Ketiga Kompenen itu adalah sebagai berikut: 1. Kahanggi (teman semarga), 2. Mora (pihak pengambilan istri). 3. Anak Boru (pihak pemberi istri). Dalihan na tolu dinalogikan sebagai tiga tungku yang biasa dipakai untuk menyangga periuk atau kuali ketika sedang memasak. jarak ketiga tungku sama sehingga ketiganya dapat menyangga dengan kokoh alat masak tersebut. titik tumpu tungku bersama-sama mendapatkan tekanan yang sama, periuk dapat diartikan sebagai beban kewajiban bersama. karena itu, dalihan na tolu diartikan dengan tiga tungku, menunjukkan peran, kewajiban dan hak dari ketiga unsur dalam dalihan na tolu. ${ }^{4}$

Dari data yang diperoleh ada 15 kepala desa yang pernah menjabat di Desa Iparbondar, dan 15 kepala desa tersebut terus menerus di isi oleh mereka yang bersaudara antara Lubis dan Nasution. Peristiwa ini menarik untuk diteliti karena dari tahun ke tahun selalu mereka yang Marga Lubis dan Nasution yang menjadi kepala desa, padahal masih ada marga yang lain.

Penelitian terdahulu yang mengangkat tema tentang perilaku masyarakat dalam pemilihan kepala desa pernah diangkat oleh Hidayat (2018) yang berjudul "Praktik Politik Oligarki dan Mobilisasi Sumber Daya Kekuasaan Di Pilkades Desa Sitimerto Pada Tahun 2016" penelitian tersebut menganalisis tentang bagaimana perkembangan model demokrasi dan sumber kekuasaan oligarki di Desa Sitimerto Kabupaten Kediri. Penelitian Ini menggunakan pendekatan kualitatif. Kasus tersebut menarik diteliti karena Pilkades Sitimerto diduga mewakili desa dengan karakter budaya Jawa dan

\footnotetext{
${ }^{3}$ Alamsyah Alamsyah, "Dinamika Politik Pilkades di Era Otonomi Daerah Studi tentang Relasi Politik Calon Kepala Desa dengan Para Pemilih Pilkades”, Jurnal TAMANPRAJA. 1(1), 2011.

${ }^{4}$ Leyla Hilda, "Revitalisasi Kearifan Lokal Dalihan Na Tolu Masyarakat Muslim andailing dalam Menjaga Harmonisasi Lingkungan Hidup”, Jurnal Miqot 40 (1), 2016, hal 177. DOI: http://dx.doi.org/10.30821/miqot.v40i1.218
} 
penguasa oligarki cukup kuat. Hasil penelitian membuktikan bahwa sumber daya material masih dominan di dinamika politik desa Sitimerto. Politik uang adalah salah sumber daya material berfungsi mempengaruhi pemilih desa dengan makna beragam. ${ }^{5}$

Penelitian tentang Pilkades yang diangkat oleh Bustomi (2016) yang berjudul “Upaya Pemenangan Calon Kepala Desa Dalam Pemilihan Kepala Desa (Pilkades) Serentak Tahun 2015 Studi Penelitian Di Desa Brani Kulon Kecamatan Maron Kabupaten Probolinggo" Penelitian tersebut lebih banya mengkaji tentang bagaimana upaya dan strategi dari para calon kepala desa dalam memenangkan Pilkades di Desa Brani Kabupaten Probolinggo. Mengingat kondisi masyarakat di Desa Brani yang kritis dalam menilai para calon kepala desa sehingga kualitas dan kualitas dan kapabilitas sang kandidat dalam pemilihan apapun termasuk pilkades sangat menentukan untuk meraih kemenangan dalam Pilkades di Desa Brani tersebut. ${ }^{6}$

Sedangkan penelitian selanjutnya yang diangkat oleh Sofyan dalam penelitiannya yang berjudul "Partisipasi Masyarakat Dalam Pelaksanaan Pemilihan Kepala Desa (Pilkades) Di Desa Sukamulya Kecamatan Rumpin Kabupaten Bogor Tahun 2019”, penelitian tersbut mengkaji tentang adanya partisipasi masyarakat dalam pelaksanaan Pilkades di Desa Sukamulya Kabupaten Bogor. Dalam penlitiannya tersebut menjelaskan anya aspirasi dari masyarakat yang sudah berjalan dengan baik malam penyampian aspirasinya secara terbuka dan umum kepada para calon kepala desa. Dalam pelaksanaan pemilihannya masyarakat mempunyai rasa tanggung jawab dalam mengambil keputusannya dalam Pilkades di Desa Sukamulya yang sesuia dengan hati nurani dan pilihannya. $^{7}$

Perlu diteliti apakah hanya karena memiliki kekerabatan yang banyak dan memiliki pendukung yang banyak calon tersebut menang atau karena didukung pengaruh budaya masyarakat. kekerabatan tersebut muncul sebagai kekuatan untuk menang dalam pilkades juga perlu diteliti apakah ada kemungkinan munculnya kepentingan lain. Tulisan ini

\footnotetext{
${ }^{5}$ Endik Hidayat, Budi Prasetyo, Setya Yuwana, "Praktik Politik Oligarki dan Mobilisasi Sumber Daya Kekuasaan Di Pilkades Desa Sitimerto Pada Tahun 2016”, Jurnal Sospol 4 (2), 2018, hal 124-151.

DOI: $\underline{\text { https://doi.org/10.22219/sospol.v4i2.6795 }}$

${ }^{6}$ Achmad Bustomi, "Upaya Pemenangan Calon Kepala Desa Dalam Pemilihan Kepala Desa (Pilkades) Serentak Tahun 2015 Studi Penelitian Di Desa Brani Kulon Kecamatan Maron Kabupaten Probolinggo”, Gema Genggong : Jurnal Hukum, Keadilan \& Budaya 1 (1), 2016.

7 Agus Sofyan, "Partisipasi Masyarakat Dalam Pelaksanaan Pemilihan Kepala Desa (Pilkades) Di Desa Sukamulya Kecamatan Rumpin Kabupaten Bogor Tahun 2019”, Dinamika : Jurnal Ilmiah Ilmu Administrasi Negara 8 (1), 2021, hal 1-13. DOI: http://dx.doi.org/10.25157/dinamika.v8i1.4805
} 
e-ISSN : 2621-4105

mencoba memahami perilaku memilih dalam masyarakat Mandailing, apakah faktor etnis dan budaya yang mendominasi masyarakat dalam memilih, sehingga yang marga lubis dan nasution yang selalu menang, atau ada faktor lain yang menjadi pertimbangan masyarakat, dan juga ingin mengetahui bagaimana rasionalitas memilih masyarakat di Desa Iparbondar. Penelitian ini bertujuan untuk mendeskripsikan perilaku memilih masyarakat Mandailing di Desa Iparbondar dalam pemilihan kepala desa tahun 2016, dan juga menganalisis rasionalitas memilih masyarakat Desa Iparbondar dalam Pilkades tahun 2016.

\section{B. PERMASALAHAN}

1. Bagaimanakah perilaku memilih masyarakat Mandailing Natal dalam pemilihan kepala desa?

2. Bagaimanakah rasionalitas memilih masyarakat Mandailing Natal dalam pemilihan kepala desa?

\section{METODE PENELITIAN}

Penelitian yang digunakan yaitu penelitian kualitatif deskriptif. Penelitian kualitatif deskriptif adalah "berupa penelitian dengan metode atau pendekatan studi kasus (case study)". Penelitian ini memusatkan diri secara intensif pada satu obyek tertentu yang mempelajarinya sebagai suatu kasus. Data studi kasus dapat diperoleh dari semua pihak yang bersangkutan, dengan kata lain dalam studi ini dikumpulkan dari berbagai sumber. 8

Narasumber yang dipilih dalam penelitian ini yaitu calon kepala desa, kepala desa terpilih, tokoh adat/hatobangon dan juga pemilih. Untuk menguji keabsahan data yang didapat peneliti menggunakan teknik triangulasi. Triangulasi data adalah teknik pemeriksaan data yang memanfaatkan sesuatu yang lain diluar data tersebut untuk keperluan pengecekan atau sebagai pembanding data tersebut. ${ }^{9}$ Hal ini dapat peneliti capai dengan jalan yaitu membandingkan data hasil pengamatan dengan data hasil wawancara, membendingkan apa yang dikatakan orang didepan umum dengan apa yang dikatakannya secara pribadi, dan membandingkan keadaan dan perspektif seseorang dengan berbagai pendapat dan pandangan orang seperti orang yang berpendidikan lebih tinggi atau ahli dalam bidang yang sedang diteliti.

\footnotetext{
${ }^{8}$ Nawawi, Hadari. 2003, “Metode Penelitian Bidang Sosial”, Yogyakarta: Gadjah Mada University Press 2016.
}

${ }^{9}$ Moleong, Lexy, 2007, “Metodologi Penelitian Kualitatif”, Bandung : Remaja Karya, hal 330. 
e-ISSN : 2621-4105

\section{HASIL DAN PEMBAHASAN}

Keikutsertaan masyarakat dalam proses pemilihan umum tidak terlepas dari adanya bentuk perilaku memilih, latarbelakang dan pendekatan apa yang dipakai oleh pemilih hingga memutuskan untuk memilih salah satu calon kepala desa. berikut ini adalah perilaku memilih masyarakat di Desa Iparbondar pada waktu pemilihan kepala desa tahun 2016.

\section{Perilaku Memilih Masyarakat Mandailing di Desa Iparbondar}

Dari hasil penelitian ditemukan bahwa masyarakat Desa Iparbondar menggunakan pendekatan sosiologis dalam menentukan pilihannya pada waktu Pilkades. Faktor ini yang paling banyak mempengaruhi perilaku memilih yaitu faktor etnis dan lebih khususnya adalah mengenai parkahanggian atau kerabat dekat.

Dilihat dari teori perilaku terencana Ajben yaitu, Norma Subjektif dimana perilaku individu dapat termotivasi untuk memenuhi anjuran seseorang atau kelompok yang dianggap penting bagi individu tersebut, dalam kehidupan sehari-hari hubungan yang dijalin setiap individu dapat bersifat vertikal atau horizontal. hubungan vertikal adalah hubungan antara atasan-bawahan contohnya, guru-murid, orangtua-anak, dan lainnya, sedangkan horizontal adalah hubungan setara contohnya hubungan dengan teman. Pada hubungan vertikal, harapan yang dihasilkan dapat diartikan sebagai tuntutan, sehingga adanya motivasi untuk patuh terhadap tuntutan tersebut. sebaliknya hubungan horizontal terbentuk secara deskriftif sehingga konsekuensinya hanya keinginan untuk meniru atau mengikuti. $^{10}$

Dalam konteks penelitian ini dapat dilihat harapan itu ada dari hubungan vertikal. Harapan tersebut dianggap sebagai tuntutan untuk melakukannya, hubungan yang paling besar mempengaruhi pemilih adalah kekeluargaan atau kekerabatan dan ini sejalan dengan pendekatan sosiologis.

Interaksi sosial Dalihan na tolu dalam budaya Mandailing yaitu mora dan anak boru memiliki hak dan kewajiban masing-masing terhadap satu sama lain. dalam hal ini, pihak anak boru mengemban fungsi sebaagai tumba na urang siorus na lobi (si penambah yang kurang dan si pengurang yang lebih), karena kewajibannya yang demikian itu, anak boru dikenal pula sebagai na manorjak tu pudi juljul tu julu (yang menerjang ke belakang, menonjol ke depan), yang maksudnya pihak anakboru ini sudah semestinya membela

${ }^{10}$ Icek Ajzen, 2006, “Contructing a TPB Questionnare: Conseptual and Methodological Consideration” 2016. 
e-ISSN : 2621-4105

kepentingan dan kemuliaan pihak mora, atau dengan kata lain pihak anak boru harus menghormati dan memuliakan pihak mora. Di samping itu anak boru juga diibaratkan sebagai si tastus nambur (penghalau embun pagi pada semak belukar), yang artinya pihak anak boru berkewajiban sebagai perintis jalan (barisan terdepan) untuk menyelesaikan persoalan-persoalan yang dihadapi pihak mora. Pihak anak boru berkewajiban menjujulkon morana (mengangkat harkat martabat pihak mora). sebaliknya, pihak mora berkewajiban untuk elek maranak boru (menyayangi dan mengasihi pihak anakboru) agar pihak anak boru senantiasa menjujulkon morana. Kahanggi (saudara semarga) sangat penting artinya bagi setiap individu karena berbagai persoalan hidup seperti perkawinan, kematian, dan mencari nafkah, terlebih dahulu dimusyawarahkan dengan kahanggi. untuk hal ini, para orangtua senantiasa memberi nasihat untuk manat-manat markahanggi (bersikap hati-hati terhadap kahanggi) agar tidak timbul perselisihan diantara sesama mereka yang semarga.

Karena hata-hata sipaingot (nasehat) dan juga hak dan kewajiban di atas tersebut, masyarakat memiliki rasa tanggung jawab untuk memilih kerabatnya dan bahkan sudah menganggap suatu kewajiban untuk memilih kerabatnya sendiri, bisa jadi calon tersebut adalah moranya atau anak borunya ataupun kahangginya. karena itu ada sebuah kewajiban moral dimana keluarga yang harus selalu diutamakan terlebih dahulu, karena kehormatan kerabat merupakan kehormatan diri sendiri juga.

Keluarga dan politik memiliki relasi yang cukup untuk saling mempengaruhi. Posisi politik seseorang atau kelompok tertentu dapat ditentukan oleh koneksi keluarga yang kuat. Keluarga memiliki peran melahirkan seorang pemimpin politik dengan berbagai macam bentuk dukungan baik dalam bentuk dana maupun moril. Penelitian yang dilakukan oleh namun, dalam penelitiannya menemukan bahwa jika calon tersebut adalah perempuan, dipilih bukan karena kemampuannya, namun lebih disebabkan karena silsilah dalam keluarganya. ${ }^{11}$

Kasus yang terjadi di Desa Iparbondar, dimana peran keluarga disini adalah kekerabatan. kekerabatan/parkahanggian yang besar menjadi kekuatan politik dari si calon. semakin besar kelompok parkahaggian semakin banyak juga dukungan yang didapat, dan dikarenakan lingkungan yang kecil, menjadikan masyarakat lebih sering

${ }^{11}$ Astuti, Tri Marhaein Pudji, 2008, “Citra Perempuan dalam Politik”, Jurnal Studi Gender Dan Anak, 3(1), 2008, hal 1-13. 
e-ISSN : 2621-4105

berinteraksi satu sama lain dan menjadikan hubungan masyarakat semakin dekat. dan hubungan yang dekat ini menjadikan masyarakat tidak mau mengkhianati kerabatnya sendiri dengan tidak memilihnya.

Perasaan setia terhadap kerabat tersebut bukan tanpa alasan. Alasan pertama adalah karena hal ini sudah mengakar dalam budaya masyarakat Mandailing untuk selalu mengutamakan kerabat. masyarakat juga menganggap bahwa suatu saat nanti apabila terjadi sesuatu seperti musibah, yang akan membantunya adalah kerabatnya sendiri. Kedua, lingkungan yang kecil dan dekatnya hubungan masyarakat bukan tidak mungkin calon tersebut mengetahui yang mana memilih dan yang tidak memilihnya, bisa karena dia memperdiksinya atau dapat laporan dari orang lain. Jadi apabila seandainya ada kerabatnya yang tidak memilihnya ini akan berakibat kepada renggangnya hubungan persaudaraan.

Pada saat melakukan wawancara terhadap narasumber, ada beberapa narasumber yang tidak mau mengatakan siapa yang dia pilih dan apa alasan dia memilihnya. Narasumber tersebut beranggapan kalau dia mengatakan pilihannya akan berakibat buruk kedepannya, khususnya yang berhubungan dengan kerabatnya. orang Mandailing menyebutnya " sotik salana borat segona”, yaitu sedikit salah besar rusaknya. narasumber tersebut tetap tidak mau diwawanarai bahkan peneliti sudah mengatakan bahwa identitas narasumber dapat dirahasiakan.

Masyarakat pendatang dan telah manopot atau masuk kesalah satu parkahanggianpun tetap memiliki perilaku memilih yang sama yaitu karena kekerabatan dengan salah satu calon kepala desa. mereka menganggap justru karena pedatang harus memilih kahanggi sendiri. karena kahanggi yang mau ditopot/masuki telah mau menerima mereka, dan karena kahanggi itu mereka memilih kerabat yang membantu disaat mereka mengadakan acara atau saat tertimpa musibah.

Keterlibatan etnis khususnya kelompok kekerabatan masyarakat Mandailing dalam pemilihan kepala desa Iparbondar tahun 2016 sangatlah penting, karena hubungan kekerabatan masih berpengaruh terhadap pilihan pemilih. Dan seperti informasi yang peneliti dapatkan dari para calon kepala desa bahwa pemilihnya adalah mayoritas kerabatnya, tidaklah heran apabila perilaku memilih berdasarkan kekerabatan menjadi dominan dalam perilaku pemilih pada pemilu kepala desa di Iparbondar tahun 2016. 
Latarbelakang identitas etnis dan kekerabatan dari pasangan calon juga menjadi kajian bagi mereka yang ingin mencalon. Kelompok kekerabatan menjadi sebuah kekuatan politik yang nyata pada saat pemilihan kepala desa tahun 2016. Keberadaan kelompok kekerabatan digunakan oleh calon kepala desa sebagai basis suara untuk kekuatan politiknya, dapat dilihat bahwa adanya suatu pemanfaatan kelompok kekerabatan untuk mencapai tujuannya sebagai kepala desa, yaitu pada saat kampanye calon kepala desa tersebut berusaha merebut hati kerabatnya dengan mendatangi rumahnya, dan bahkan mengundangnya untuk berkumpul.

Peran dan posisi calon kepala desa dalam kelompok kekerabatannya juga sangat penting, selain karena ada ikatan kekerabatan yang dimiliki, calon yang posisinya sebagai amangna (ayah) dalam kelompok kekerabatannya, tentunya lebih dihargai kerena lebih dituakan. Dan juga keaktifan dalam acara adat yang diadakan oleh kerabatnya, membantu dalam acara nikahan, mangkobar (memberikan sambutan atau nasehat dalam acara), membantu dalam musibah meninggal, dan lainnya. Calon yang aktif membantu dalam kegiatan tersebut masyarakat menganggapnya sebagai orang yang berjiwa sosial tinggi. Oleh karena itu kegiatan dalam kelompok kekerabatan yang dimiliki oleh calon juga menjadi referensi kerabatnya untuk memilih, apalagi jika kejadian lebih dari satu yang berasal dari kelompok kekerabatan yang sama mencalon sebagai kepala desa seperti yang terjadi pada pemilihan kepala desa Iparbondar tahun 2016.

Dari penjelasan di atas dapat kita lihat bahwa kelompok etnis mempunyai peranan besar dalam membentuk sikap, persepsi, dan orientasi perseorangan. Sistem kekerabatan pada masyarakat Mandailing di Desa Iparbondar masih sangat kuat, dengan adanya Dalihan na tolu yang meliputi mora, kahanggi, anakboru tersebut. Pengaruh nilai adat Dalihan na tolu ini sangat jelas ketika penyelengaran pemilihan kepala desa Iparbondar tahun 2016, dimana preferensi memilh masyarakat dikerenakan masyarakat masih memiliki pemikiran lebih mengutamakan hubungan kekerabatan.

Pada dasarnya perilaku politik berdasarkan kekerabatan memunculkan pro dan kontra, sebagian ada yang menganggap baik karena kestabilan politik terjaga, karena pemerintahan akan diisi oleh mereka dari mayoritas, dan sebagian pula menganggap kekerabatan tersebut hanyalah alat yang digunakan para pejabat untuk mendapatkan kekuasaan. selain itu perilaku politik berdasarkan kekerabatan akan mempersempit 
e-ISSN : 2621-4105

kesempatan bagi orang lain berpartisipasi lebih untuk menjadi kepala desa, karena biasanya pemimpin hasil dari kelompok kekerabatan lebih banyak dukungan. Namun tidak menutup kemungkinan bahwasanya suatu tingkatan wilayah desa masih menggunakan peran kekerabatan dalam seleksi demokrasi karena ini adalah cara yang sah untuk dilakukan.

Selain pendekatan sosiologis, perilaku memilih berdasarkan pendekatan psikologis juga ditemukan dalam penelitian ini. Mayoritas narasumber sudah mengenal dengan baik calon kepala desa yang mereka pilih. Pergaulan yang luas dan didukung oleh kekerabatan dengan jumlah yang lebih banyak, narasumber di atas umumnya menyatakan memilih atas pertimbangan lebih mengenal figur kepala desa dan mempertimbangkan kelayakan dari unsur pengalaman calon dan kemampuan dalam pemerintahan desa.

Berdasarkan teori perilaku terencana yaitu perilaku didasarkan oleh unsur evaluasi dari pengalaman dapat dikategorikan sebagai perilaku Behavior beliefs, yaitu Beliefs seseorang terhadap konsekuensi positif atau negatif yang akan diperoleh seseorang apabila melakukan suatu perilaku, keyakinan ini dapat memperkuat sikap terhadap perilaku itu apabila berdasarkan evaluasi yang dilakukan individu. misalnya bahwa seseorang tersebut memiliki keyakinan bahwa harus memilih berdasarkan kepercayaan yang ada dalam masyarakat, disamping itu yang membentuk keyakinan tersebut adalah pengalaman terdahulu. Dalam penelitian ini ditemukan bahwa keyakinan pemilih terhadap calon kepala desa muncul karena melihat pengalaman sebelumnya, baik itu pengalaman dalam hal menjalankan adat istiadat ataupun pengalaman pernah menjabat sebelumnya.

Seperti yang disampaikan oleh Muhammad Lubis ( 59 tahun, PNS ) bahwa ia memilih calon karena pernah menjabat kepala desa sebelumnya, hal yang sama juga disampaikan oleh Muaz Nasution (23 tahun, Mahasiswa), Asridah (51 tahun, petani) dan Likah Lubis (25 tahun, Guru). Keyakinan berdasarkan evaluasi yang dilakukan individu tersebut dapat memperkuat sikap terhadap perilaku memilihnya. dengan evaluasi tersebut pemilih dapat menimbang konsekuensi yang didapat jika mamilih atau tidak memilih calon tersebut.

Dengan mengenal figur kepala desa juga sudah cukup bagi narasumber untuk yakin menentukan pilihan dalam pemilihan kepala desa Iparbondar tanpa harus adanya 
e-ISSN : 2621-4105

wawasan memadai dalam pemerintahan desa. Rekam jejak atau pengenalan diri seorang calon pemimpin sangat diperlukan oleh calon pemilih. Menurut Dieter Roth (2009), keputusan seseorang untuk ikut memilih atau tidak ditentukan oleh kedekatan dengan partai atau kandidat yang maju dalam pemilihan. Makin dekat seseorang dengan partai atau kandidat tertentu makin besar kemungkinan seseorang terlibat dalam pemilihan. ${ }^{12}$

Perilaku merupakan salah satu unsur penting untuk menunjukkan siapa diri kita sebenarnya, perilaku seseorang terbentuk dari perjalanan pengalaman masa lalu, keberhasilan, kegagalan, pengetahuan yang dimilikinya, dan bagaimana orang lain telah menilainya secara obyektif. Di bawah ini Andriyus (2013: 34) menjelaskan yang termasuk ke dalam perilaku dari calon tersebut adalah ${ }^{13}$ :

\section{1) Visi dan Misi}

Visi merupakan suatu pandangan kedepan yang akan menjadi sasaran ataupun tujuan akhir dari suatu kegiatan. sedangkan misi merupakan kegiatan-kegiatan yang dilakukan dalam rangka untuk mencapai visi tersebut. Visi misi sangat diperlukan bagi organisasi atau orang untuk menentukan arah dan tujuan dari sebuah organisasi. dan bagi calon kepala desa visi dan misi yang jelas dan masuk akal sangat diperlukan untuk menarik suara dari masyarakat.

\section{2) Kualitas Komunikasi dan Kampanye}

Kualitas komunikasi dari seorang kandidat marupakan salah satu faktor yang sangat penting dalam menarik partisipasi politik masyarakat. seorang kandidat dalam berkampanye dapat meyakinkan masyarakat untuk ikut berpartisipasi dalam proses pemilu tersebut.

3) Tanggungjawab dalam menepati janji-janji Politik

Tanggungjawab dalam menepati janji politik merupakan salah satu faktor yang juga dapat mempengaruhi perilaku memilih masyarakat. Sejauh mana kandidat dapat meyakinkan masyarakat jika terpilih dia akan menepati janji-janji politiknya dimasa kampanye. Bagi calon yang pernah menjabat sebelumnya pengalaman merupakan salah satu faktor kekuatan dalam menarik suara masyarakat. Janji-janji politik calon

${ }^{12}$ Achmad Bustomi, "Upaya Pemenangan Calon Kepala Desa Dalam Pemilihan Kepala Desa (Pilkades) Serentak Tahun 2015 Studi Penelitian Di Desa Brani Kulon Kecamatan Maron Kabupaten Probolinggo”, Gema Genggong : Jurnal Hukum, Keadilan \& Budaya 1 (1), 2016.

${ }^{13}$ Andriyus Andriyus, "Faktor-Faktor Yang Mempengaruhi Partisipasi Politik Masyarakat Pada Pemilihan Umum Legislative 2009 Di Kecamatan Singingi Hilir Kabupaten Kuantan Singingi”, Jurnal Kajian Ilmu Pemerintahan, 2(2), 2013, hal 34. 
e-ISSN : 2621-4105

sebelumnya sudah diimplementasikan dan masyarakat sudah melihat dan merasakannya, dari pengalaman tersebut masyarakat sebagai pemilih dapat menilai apakah calon tersebut pantas untuk dipilih kembali.

Selain pendekatan di atas, kegiatan memilih sebagai produk kalkulasi untung dan rugi atau pendekatan rasional juga ditemukan dalam penelitian ini, yang dipertimbangkan tidak hanya "ongkos" memilih dan kemungkinan suaranya dapat mempengaruhi hasil yang diharapkan tetapi juga perbedaan dari alternatif berupa pilihan yang ada. bagi pemilih pertimbangan untung dan rugi digunakan untuk membuat keputusan tentang partai atau kandidat yang dipilih, terutama untuk membuat keputusan apakah ikut memilih atau tidak ikut memilih. Kemampuan mengontrol dilakukan atau tidak dilakukan perilaku tertentu dalam teori perilaku terencana Ajben disebut sebagai Control beliefs. Beliefs ini didasarkan pada pengalaman terdahulu individu tentang suatu perilaku, informasi yang dimiliki individu tentang suatu suatu perilaku yang diperoleh dengan melakukan observasi pada pengetahuan yang dimiliki diri maupun orang lain yang dikenal individu, dan juga oleh berbagai faktor lain yang dapat meningkatkan ataupun menurunkan perasaan individu mengenai tingkat kesulitan dalam melakukan suatu perilaku.

Dalam konteks penelitian ini, pemilih dapat dengan mudah mendapatkan informasi mengenai calon karena wilayah yang lebih kecil, informasi itu dapat diperoleh dari pengalaman sendiri ataupun diperoleh dari orang lain. pengetahuan pemilih tentang calon dapat menjadi faktor pendukung atau penghambat bagi pemilih dalam menentukan pilihannya. Semakin pemilih merasakan banyak faktor pendukung dan sedikit faktor penghambat untuk dapat memilih calon tersebut, atas pertimbangan tersebut maka lebih besar kontrol yang mereka rasakan untuk memilih calon tertentu dan begitu juga sebaliknya.

Dalam penelitian pemilih yang bertindak seperti yang dijelaskan contohnya adalah para tim sukses calon kepala desa tersebut, seperti yang dijelaskan oleh Pak Thamrin narasumber tim sukses dari calon nomor dua, dimana beliau menjelaskan bahwa beliau mendukung karena telah memprediksi jumlah suara yang akan mereka peroleh, beliau melakukan observasi dan terbukti bahwa pertimbangannya tidak meleset jauh. Mereka mendukung dan memilih calon tersebut karena sebelumnya sudah mempertimbangkan 
e-ISSN : 2621-4105

hasil pemilihan, dan mengupayakan untuk mencapai tujuan tersebut, selain itu pertimbangan apa yang mereka peroleh setelah mendukung juga menjadi pertimbangan tim sukses tersebut, seperti yang dijelaskan oleh narasumber Muksan, bahwa beliau mendukung calon nomor satu karena jika nantinya calon yang didukungnya tersebut menang, nasehat dan masukan darinya untuk pembangunan desa akan didengarkan oleh calon tersebut.

\section{Rasionalitas memilih masyarakat Mandailing di Desa Iparbondar}

Pendekatan pilihan rasional melihat kegiatan memilih sebagai produk kalkulasi untung dan rugi. yang dipertimbangkan tidak hanya ongkos memilih dan kemungkinan suaranya dapat mempengaruhi hasil yang diharapkan, tetapi juga perbedaan dari alternatif berupa pilihan yang ada. Tindakan rasional menurut Weber (dalam Umanailo, 2019) adalah tindakan ekonomi, yang dipahami dalam sudut pandang marginalis dalam hubungannya dengan pilihan-pilihan yang dipilih secara sadar, aktor yang berorientasi ekonomi adalah mereka yang bertindak secara strategis, yang menggunakan teknik yang tepat untuk meraih tujuan mereka. Weber (dalam Turner, 2012) menjelaskan semakin rasional tindakan sosial itu semakin mudah pula dipahami. Empat tipe tindakan sosial tersebut antara lain: rasional instrumental, rasional berorientasi nilai, tindakan tradisional dan tindakan afektif.

Rasionalitas Instrumental, adalah tindakan yang ditentukan oleh harapan-harapan yang memiliki tujuan untuk dicapai dan menentukan nilai dari tujuan itu sendiri. Dalam penelitian ini pemilih yang bertindak seperti yang dijelaskan adalah para tim sukses calon kepala desa tersebut, mereka mendukung dan memilih calon tersebut karena sebelumnya sudah mempertimbangkan hasil pemilihan, dan mengupayakan untuk mencapai tujuan tersebut.

Rasionalitas Nilai, yaitu tindakan yang didasari oleh kesadaran keyakinan mengenai nilai-nilai yang penting seperti etika, estetika, agama, dan nilai-nilai lainnya yang mempengaruhi tingkah laku manusia dalam kehidupannya. dalam penelitian ada beberapa pemilih yang merasa yakin akan pilihannya dan mengabaikan hal yang biasa dilakukan orang lain, seperti M. Amrin Lubis ( 51 tahun, Petani) menyatakan bahwa ia tidak memilih kerabatnya sendiri seperti yang banyak orang lain lakukan, tapi ia memilih calon yang lain karena merasa yakin bahwa calon tersebut lebih layak untuk memimpin 
e-ISSN : 2621-4105

jika dilihat dari latarbelakang keluarganya, dan juga sikapnya sehari-hari. Weber (dalam Umanailo, 2019) mengatakan bahwa tidakan ini masih rasional meski tidak serasional tindakan rasional instrumental, sehingga tindakannya masih dapat dipahami.

Tindakan Afektif, merupakan tindakan yang ditentukan oleh kondisi kejiwaan dan perasaan individu yang melakukannya, tindakan ini dilakukan seseorang berdasarkan perasaan yang dimilikinya, biasanya timbul secara spontan begitu mengalami suatu kejadian. dalam penelitian yang dilakukan beberapa narasumber memilih calon karena merasa berterimakasih kepada calon tersebut atas perbuatan baiknya dimasa lalu. Tindakan ini sukar dipahami karena kurang rasional.

Tindakan Tradisional, yaitu tindakan yang ditentukan oleh kebiasaan-kebiasaan yang sudah mengakar secara turun temurun. dalam penelitian ini tindakan tradisional adalah tindakan yang paling banyak dilakukan pemilih, yaitu berdasarkan kekerabatan, karena Parkahanggian, dan juga karena poda-poda ni dainang (nasehat orangtua) untuk selalu mendahulukan kerabat sendiri dalam segala hal. kebiasaan ini sudah turun temurun dalam kehidupan masyarakat Mandailing. Tindakan ini juga sukar dipahami karena kurang rasional bahkan tidak rasional.

Merujuk dari penjelasan teori Weber tentang rasionalitas tindakan sosial di atas dapat kita temukan bahwa sebagian besar masyarakat Mandailing di Desa Iparbondar masih kurang rasional dalam memilih, karena masyarakatnya masih banyak memilih berdasarkan parkahanggian/kekerabatan yang merupakan kebiasaan masyarakat.

\section{E. PENUTUP}

Kesimpulan dari hasil penelitian yang dilakukan peneliti adalah Perilaku memilih masyarakat Desa Iparbondar dalam pemilihan kepala desa tahun 2016, dimana pemilih cenderung menentukan pilihan berdasarkan pendekatan sosiologis yaitu kekerabatan, dimana ada rasa tanggungjawab untuk memilih kerabat sendiri. Tanggungjawab tersebut muncul karena adanya adat istiadat yang telah mengakar kuat dalam kehidupan masyarakat. Dari penelitian yang dilakukan, pemilih dari masyarakat Mandailing di Desa Iparbondar sebagian besar masih kurang rasional, karena dari data wawancara yang didapatkan bahwa pemilih lebih cenderung memilih berdasarkan pendekatan sosiologis yaitu kekerabatan. 
e-ISSN : 2621-4105

\section{DAFTAR PUSTAKA}

\section{Buku}

Ajzen, I, 1991, “Theory of Planned Behavior”, Organizational Behavior and Human Decision, Processes 50.

- 2006. "Contructing a TPB Questionnare: Conseptual and Methodological Consideration".

Moleong, Lexy, 2007. “Metodologi Penelitian Kualitatif”, Bandung : Remaja Karya. 330

Nawawi, Hadari, 2003, "Metode Penelitian Bidang Sosial”, Yogyakarta: Gadjah Mada University Press.

Sastroatmodjo, Sudijono, 1995. “Perilaku Politik”, Semarang: IKIP Semarang Press

\section{Jurnal}

Achmad Bustomi, "Upaya Pemenangan Calon Kepala Desa Dalam Pemilihan Kepala Desa (Pilkades) Serentak Tahun 2015 Studi Penelitian Di Desa Brani Kulon Kecamatan Maron Kabupaten Probolinggo”, Gema Genggong : Jurnal Hukum, Keadilan \& Budaya 1 (1), 2016.

Agus Sofyan, "Partisipasi Masyarakat Dalam Pelaksanaan Pemilihan Kepala Desa (Pilkades) Di Desa Sukamulya Kecamatan Rumpin Kabupaten Bogor Tahun 2019”, Dinamika : Jurnal Ilmiah Ilmu Administrasi Negara 8 (1), 2021.

DOI: http://dx.doi.org/10.25157/dinamika.v8i1.4805

Alamsyah Alamsyah, "Dinamika Politik Pilkades di Era Otonomi Daerah Studi tentang Relasi Politik Calon Kepala Desa dengan Para Pemilih Pilkades", Jurnal Tamanpraja. 1(1), 2011.

Andriyus Andriyus, “Faktor-Faktor Yang Mempengaruhi Partisipasi Politik Masyarakat Pada Pemilihan Umum Legislatif 2009 Di Kecamatan Singingi Hilir Kabupaten Kuantan Singingi”, Jurnal Kajian Ilmu Pemerintahan, 2(2), 2013, hal 34

Astuti, Tri Marhaein Pudji, 2008. Citra Perempuan dalam Politik , Jurnal studi gender dan Anak, 3(1).

Leyla Hilda, "Revitalisasi Kearifan Lokal Dalihan Na Tolu Masyarakat Muslim andailing dalam Menjaga Harmonisasi Lingkungan Hidup", Jurnal Miqot 40 (1), 2016.

DOI: http://dx.doi.org/10.30821/miqot.v40i1.218

Endik Hidayat, Budi Prasetyo, Setya Yuwana, "Praktik Politik Oligarki dan Mobilisasi Sumber Daya Kekuasaan Di Pilkades Desa Sitimerto Pada Tahun 2016”, Jurnal Sospol 4 (2), 2018.DOI: https://doi.org/10.22219/sospol.v4i2.6795

Widagdo, Suwignyo, 2016. Peran Ketokohan, Ikatan Emosional dan Program Kerja dalam Memengaruhi perilaku Memilih (Pendekatan Pemasaran Politik dalam Pemilihan Calon Kepala Desa). Dinamika Global: Rebranding Keunggulan Kompetitif Berbasis Kearifan Lokal, e-Proceeding

\section{Karya Ilmiah}

Sebayang, Irma S. "Perilaku Pemilih Etnis Karo dalam Pemilihan Bupati Kabupaten Karo Periode 2010-2015”. Skripsi, Medan : Fisipol USU, 2012. 
e-ISSN : 2621-4105

\section{Internet}

https://researchgate.net/publication/336763591. 